\title{
GAMBARAN SEL EPITEL PADA LESI PAYUDARA DILABORATORIUM PATOLOGI ANATOMI UPT RSUD DELI SERDANG LUBUK PAKAM
}

\section{Kartini $^{1}$, Asti Pratiwi ${ }^{2}$, Visensius Krisdianilo${ }^{1}$, Bambang Sumantri $^{1}$, Rimayani Sidabutar ${ }^{1}$}

\author{
${ }^{1}$ Program Studi Teknologi Laboratorium Medik, Institut Kesehatan Medistra \\ Lubuk Pakam \\ ${ }^{2}$ Program Studi Farmasi, Institut Kesehatan Medistra Lubuk Pakam
}

\author{
Jln. Sudirman No.38 Lubuk Pakam, Kabupaten Deli Serdang, \\ Sumatera Utara - Indonesia \\ *email : kartini276@gmail.com \\ DOI $10.35451 /$ jfm.v3i2.624
}

\begin{abstract}
:
The breast is an organ that grows as a tissue bulge that is first seen at 7 to 8 weeks after conception. Each breast consists of 12 to 20 tubuloalveolar gland lobules. Each lobule consists of cells consisting of cube epithelial cells and myoepithelial cells that surround the lumen. Lesions in the breast can originate from a connective tissue or from epithelial cells that develop continuously. Some types of epithelial cell traces in breast lesions include fibroadenoma, tumor filoides, papillomas, and papillary carcinoma, and breast carcinoma. This study aims to determine the description of epithelial cells in breast lesions in the Anatomical Pathology Laboratory of UPT Deli Serdang Lubuk Pakam Hospital Period 2018 - 2019. The research was conducted descriptively using the Fine Needle Aspiration Biopsy (FNAB) examination method. The study was conducted using secondary obtained from the medical record of the Anatomical Pathology Laboratory of UPT Deli Serdang Lubuk Pakam Hospital about the description of epithelial cells in breast lesions. The results showed that there were 6 epithelial cell features in breast lesions in the Anatomy Pathology Laboratory of UPT Deli Serdang Hospital. The six epithelial cell features include mammary aberans, mammary adenoma fibrio, mammary dysplasia, mammary multiple fibroadenoma, mammary ductal hyperplasia and mammary carcinoma. From a total of 30 study samples obtained 14 epithelial cells in the form of mammary adenoma fibrio (46.67\%). Description of epithelial cells in the form of mammary aberans as manyas 7 people (23.33\%). For depictions of epithelial cells in the form of mammary carcinoma by 6 people (20\%). While the epithelial picture in the form of mammary dysplasia, multiple fibroadenoma mammary and mammary ductal hyperplasia each as much as 1 person (3.33\%).
\end{abstract}

Keywords : Lesi Payudara, Sel epitel. 


\section{PENDAhUluan}

Payudara merupakan organ yang tumbuh seperti gumpalan jaringan yang terlihat pada usia minggu ke 7 sampai 8 setelah konsepsi. Pada fase selanjutnya diusia kehamilan 16 minggu akan terbentuk suatu tojolan yang lebih jelas. Payudara akan lebih besar pada awal masa pubertas karena dipengaruhi hormon estrogen dan progesterone, selanjutnya akan mengalami pematangan dalam jangka waktu $3-4$ tahun (Harahap, 2015). Setiap payudara tersusun 12 hingga 20 lobulus kelenjar tubuloalveolar yang memiliki saluran ke puting susu. Di kelenjar susu dan fasia pektoralis dan diantara kulit dan kelenjar payudara terdapat jaringan lemak.

Setiap lobulus memiliki sel asini yang mengelilingi lumen yaitu sel epitel kubus dan mioepitel. Sel epitel berada di lumen, sel miopitel berada di antara sel epitel dan membran basalis (Haryono et al, 2011). Pada epitel payudara reseptor terhadap esterogen dan progesteron akan terjadi ikatan dengan pembawa sel kanker, transforming growth factor alfa yang berikatan dengan faktor yang berada pada lapisan epitel dan fibroblast yang menciptakan mekanisme autokrin lesi dan tumor.

Faktor lain yang memepngaruhi munculnya lesi dan tumor antara lain pola makan, obesitas, olah raga, menyusui, faktor lingkungan dan kebiasaan merokok (Haryono et al, 2011). Lesi pada payudara merupakan keluhan yang paling sering ditemui pada wanita dengan penyakit payudara. Dari tahun ke tahun insidensi lesi jinak mengalami peningkatan begitu juga lesi yang ganas seperti kanker payudara (YKI, 2011).

Hasil penelitian Irwig et al (2012) menunjukkan bahwa persentase seseorang yang memiliki keluhan lesi pada payudara yaitu sebanyak $30 \%$ tida ada penyakit, $10 \%$ kankerpayudara, $7 \%$ fibroadenoma, $\quad 40 \%$ perubahan fibrokistik dan $13 \%$ lesi jinak lainnya. Sebanyak $80 \%$ lesi yang muncul di payudara adalah jinak. Namun, adanya lesi pada payudara yang ditemukan pada pemeriksaan fisik harus tetap diwaspadai dan dievaluasi dengan cermat.

Pemeriksaan anamnesa, fisik, imaging dan patologi seperti aspirasi jarum halus dan biopsi terbuka (Harahap, 2015). Pada umumnya kanker atau tumor pada payudara bermula dari sel epitel yang mengalami pembelahan secara terus menerus. Beberapa penampaakan sel epitel pada payudara antara lain karsinoma mammae dan sarcoma. Sarkoma merupakan kelainan payudara yang berasal dari jaringan penghubung.

Kanker ini bersifat ductal breast canser dengan pertumbuhan yang lambat. Lesi pada payudara dapat berasal dari sebuah jaringan ikat atau dari sel epitel yang berkembang secara terus - menerus. Beberapa jenis gampabaran sel epitel pada lesi payudara antara lain yaitu fibroadenoma, tumor filoides, papiloma, dan karsinoma papilaris, serta karsinoma payudara (Kumar et al, 2007). Diagnosis awal lesi pada payudara dapat dilakukan dengan metode (FNAB) atau dikenal dengan biopsy jarum halus. Keunggulan FNAB yang dilakukan tidak invasif dan mempunyai akurasi yang terpercaya. Pada dasarnya FNAB berfungsi untuk mendapatkan sampel sel-sel nodul pada payudara yang teraspirasi melalui penusukan jarum ke jaringan nodultiroid (Hartati, 2016).

RSUD Deli Serdang memiliki IGD, ICU, NICU, PICU, IBS, rawat inap, rawat jalan, radiologi, patologi klinik, 
Received: 12 April 2021 :: Accepted: 28 April 2021 :: Published: 30 April 2021

laboratorium, farmasi, gizi, UTD-RS, pengelolaan limbah medis, dan pelayanan yang lainnya.

Pemeriksaan awal lesi yang muncul di payudara sangat penting untuk dilakukan, untuk melihat gambaran sel epitel pada lesi tersebut. Salah satu metode yang dikenal akurat dan memerlukan waktu yang relatif singkat untuk melihat gambaran sel epitel tersebut adalah dengan metode FNAB. Pemeriksaan ini dikenal luas digunakan dalam mendiagnosis lesi dan kanker payudara serta sudah dikenal sejak tahun 1930 (Suen \& Kenneth, 2010).

Hal ini yang melatar belakangi penulis melakukan penelitian dengan judul gambaran sel epitel pada lesi payudara di Laboratorium Patologi Anatomi UPT RSUD Deli Serdang Lubuk Pakam.

\section{METODE}

\section{JENIS PENELITIAN}

Metode jenis penelitian dengan menggunakan metode deskriptif yang bertujuan untuk melihat gambaran sel epitel pada lesi payudara di Laboratorium Patologi Anatomi UPT RSUD Delis Serdang Lubuk Pakam

\section{Alat dan Object Penelitian}

Alat dan Object Penelitian Alat-alat yang digunakan antara lain: spuit $10 \mathrm{cc}$, penyangga spuit, slide kaca, mikroskop Object penelitian yang digunakan adalah sel epitel pada lesipayudara Pengambilan Object Penelitian

\section{Pengambilan Object Penelitian}

Penelitian tentang gambaran sel epitel pada lesi payudara menggunakan teknik FNAB atau aspirasi jarum halus yang mengambil sebagian jaringan tubuh manusia dengan diameter kecil. Tujuannya untuk diagnosis
1. Siapkan jarum yang sudah terpasang pada spuit $10 \mathrm{cc}$ dan dapat dibantu dengan penyangga spuit untuk mempermudah aspirasi.

2. Fiksasi massa menggunakan 2 jari dari tangan yang tidak dominan.

3. Menggunakan tangan yang dominan, tusuk jarum hingga menembus kulit atau mukosa secara cepat, lanjutkan hingga mencapai target.

4. Pada target yang superfisial, jarum di introduksi pada sudut 30-45 derajat. Untuk massa yang lebih dalam, gunakan sudut yang lebih tegak lurus

5. Setelah ujung jarum berada di dalam massa, lakukan suction dengan menarik kembali plunger jarum suntik

6. Sambil mempertahankan suction, gerakkan jarum dengan cepat ke depan dan ke belakang. Jarum dipertahankan di dalam target dan tidak keluar dari kulit.

7. Lepaskan tekanan negatif setelah pengambilan sampel selesai, sebelum menarik jarum dari massa

8. Tarik jarum dari massa dan persiapkan apusan

9. Setelah ditarik, lepaskan spuit dari jarum. Isi spuit dengan udara dan pasang kembali ke jarum yang mengandung specimen.

10. keluarkan spesimen ke slide kaca

11. amati di bawah mikroskop untuk melihat gambaran sel epitel

Tabel 1. Data gambaran sel epitel pada lesi payudara di laboratorium patologi Anatomi UPT RSUD Deli Serdang Lubuk Pakam

\section{Prosedur Kerja}


Jurnal Farmasi, e-ISSN: 2655-0814

Vol. 3 No.2 Edisi Mei-Oktober 2021

http://ejournal.medistra.ac.id/index.php/JFM

Received: 12 April 2021 :: Accepted: 28 April 2021 :: Published: 30 April 2021

\section{Hasil dan Pembahasan}

Penelitian tentang gambaran sel epitel pada lesi payudara di Laboratorium Patologi Anatomi UPT RSUD Deli Serdang Lubuk Pakam, telah dilakukan terhadap 30 sampel penelitian. Hasil penelitian tersebut disajikan pada tabel 1 berikut ini. yang mempengaruhi munculnya lesi pada payudara antara lain hormon, pola makan, aktivitas fisik, dan juga tingkat stres seseorang. Gaya hidup yangtidak sehat merupakan faktor utama penyebab munculnya lesi di payudara.

Hasil penelitian menunjukkan bahwa terdapat 6 gambaran sel epitel

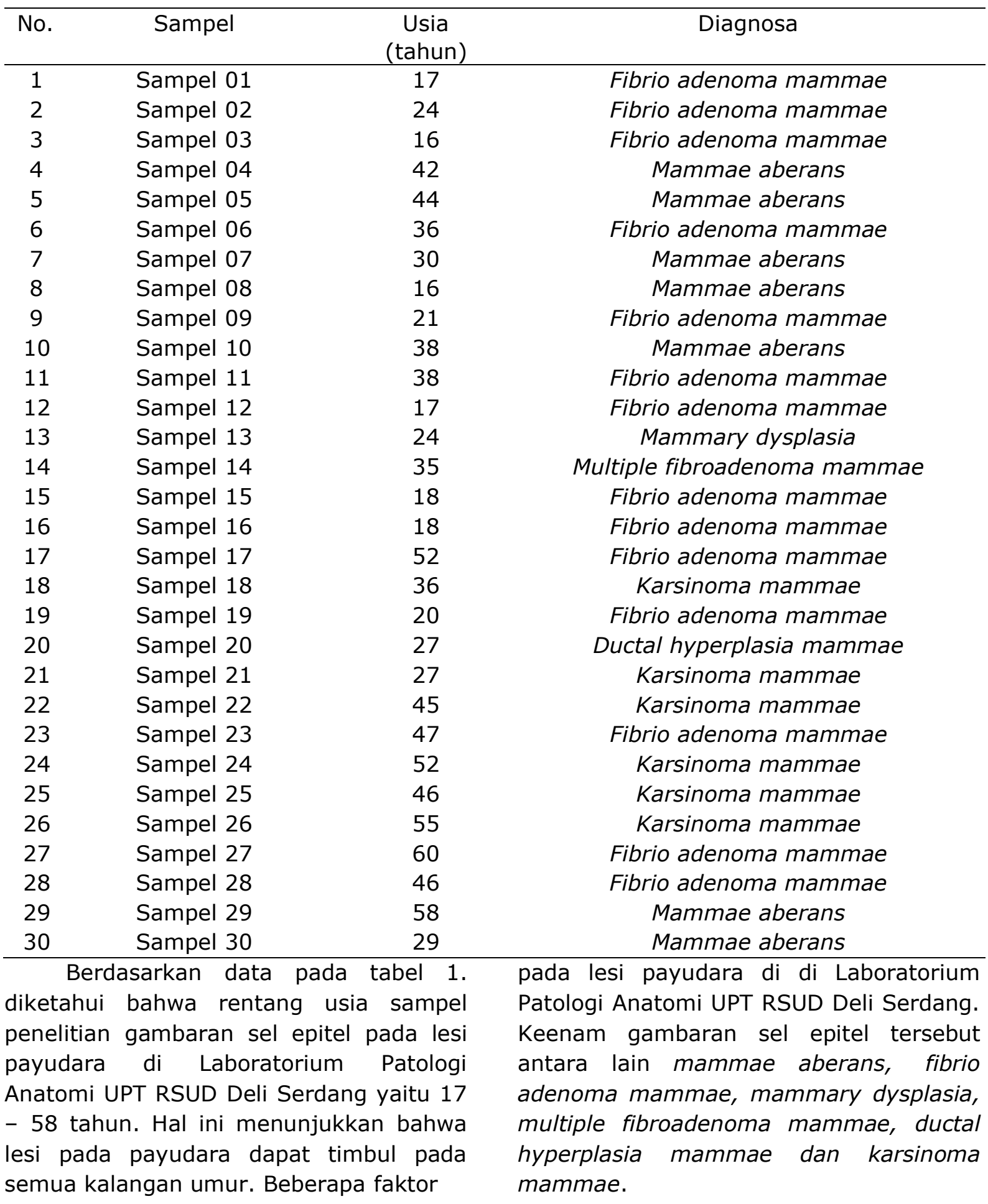


Received: 12 April 2021 :: Accepted: 28 April 2021 :: Published: 30 April 2021

Dari total 30 sampel penelitian didapatkan gambaran sel epitel berupa fibrio adenoma mammae sebanyak 14 orang $(46,67 \%)$. Gambaran sel epitel berupa mammae aberans sebanyak 7 orang $(23,33 \%)$. Untuk gambaran sel epitel berupa karsinoma mammae sebanyak 6 orang (20\%). Sedangkan gambaran epitel berupa mammary dysplasia, multiple fibroadenoma mammae dan ductal hyperplasia mammae masing - masing sebanyak 1 orang $(3,33 \%)$. Dari data tersebut diketahui bahwa gambaran sel epitel terbanyak berupa fibrio adenoma mammae.

Fibroadenoma mammae merupakan salah satu jenis tumor jinak payudara yang paling sering dialami oleh wanita berusia antara 15-35 tahun. Tumor ini berukuran kecil dengan tekstur yang padat dan mudah digerakkan (Gambar 1).

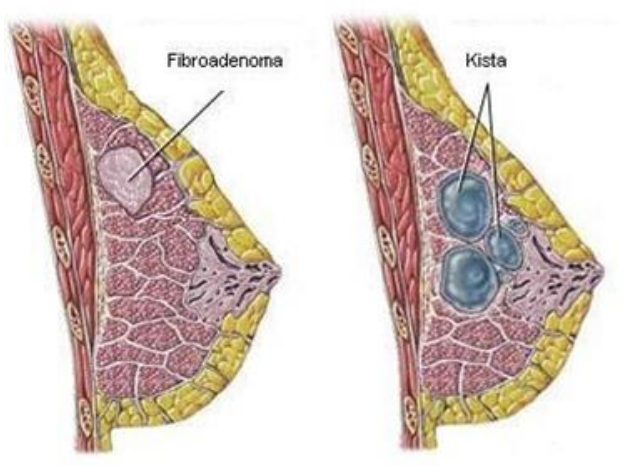

Gambar 1. Fibroadenoma mammae pada payudara

Mammae aberans merupakan kondisi kelenjar terdapatnya jaringan payudara tambahan selain payudara yang normal. Kelenjar ini berlokasi pada ketiak kanan dan kiri namun bisa juga tumbuh dibawah dada dan perut segaris dengan garis puting. Mammae aberans tidak memerlukan penanganan, kecuali jika ukurannya sangat besar dan menimbulkan rasa nyeri jika terjadi menstruasi. Penanganan yang dapat dilakukan adalah Tindakan operasi. Mammae aberans adalah sel yang tidak normal yang terus tumbuh menjadi banyak sehingga membentuk benjolan di payudara.

Karsinoma mammae adalah sekelompok sel yang tidak normal pada payudara yang terus tumbuh berlipat ganda. Pada akhirnya sel - sel ini menjadi bentuk benjolan di payudara. Karsinoma mammae merupakan salah satu bentuk pertumbuhan sel atau pada payudara. Dalam tubuh terdapat berjuta-juta sel. Salah satunya, sel abnormal atau sel metaplasia, yaitu sel yang dapat berubahubah tetapi masih dalam batas normal (Humaera \& Mustofa, 2017).
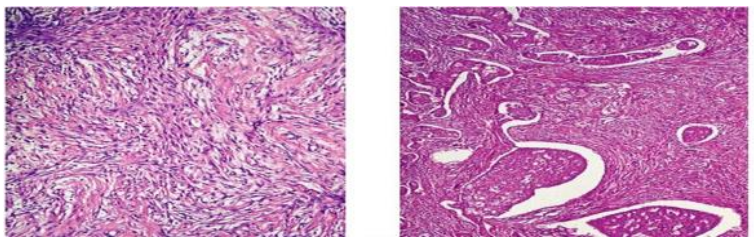

Gambar 2. Karsinoma mammae metaplasia pada payudara

Karsinoma pada payudara termasuk kelompok tumor ganas epitel yang memiliki karakteristik adanya invasi ke jaringan sekitarnya dan ditandai dengan adanya kecendrungan mengalami metastasis yang luas ke area payudara. Pada dasarnya tumor dipercaya berasal dari epitel parenkim seperti sel dari unit duktus lobular terminalis (Ellis, 2013).

Payudara mengalami banyak perubahan akibat hormon. Estrogen dan progesterin pada masa pubertas dihasilkan oleh ovarium dan hipofisa anterior sehingga menyebabkab duktus dan asinus berkembang.

Terjadi peningkatan estrogen dan progesteron pada saat menstruasi menyebabkan proliferasi sel dan retensi cairan. Saat hamil, proliferasi sel terjadi karena estrogen, progesteron, laktogen plasenta dan prolaktin. Saat menyusui produksi prolaktin akan meningkat dan estrogen akan menurun. Saat menopause berkurangnya jumlah kelenjar dan involusi payudara (Montag \& Kumar, 2017). 
Received: 12 April 2021 :: Accepted: 28 April 2021 :: Published: 30 April 2021

Payudara tersusun dari lobulus, duktus, lemak, jaringan konektif, pembuluh darah dan limfe. Kanker berasal dari sel duktus dan lobulus serta jaringan lainnya (Thor \& Osunkoya, 2010).

Pemeriksaan fisik untuk mendiagnosis karsinoma mammae adalah mencakup pemeriksaan fisik menyeluruh (sesuai pemeriksaan rutin) dan pemeriksaan kelenjar mammae. Perhatikan ada atau tidak benjolan atau perubahan patologi kulit seperti cekungan, merah, bengkak, erosi, nodul satelit, perhatikan juga kedua papila mammae apakah terjadi berubahan bentuk, retraksi, distorsi dan erosi (Humaera \& Mustofa, 2017).

Mammary displasia yaitu suatu keadaan munculnya benjolan pada payudara karena siklus ekstrogen atau hormonal pada wanita. Diagnosis penyakit ini dapat dilakukan dengan biopsis, Fine Needle Aspiration Biopsy atau USG. Terapi yang dilakukan yaitu eksisi (pembuagan tumor).

\section{Kesimpulan}

Berdasarkan penelitian yang dilakukan maka dapat disimpulkan beberapa hal yaitu:

1. Gambaran sel epitel dari lesi payudara antara lain mammae aberans, fibrio adenoma mammae, mammary dysplasia, multiple fibroadenoma mammae, ductal hyperplasia mammae dan karsinoma mammae.

2. Gambaran sel epitel berupa fibrio adenoma mammae merupakan yang paling banyak ditemukan yaitu sebanyak 14 orang $(46,67 \%)$.

3. Gambaran sel epitel berupa mammae aberans sebanyak 7 orang (23,33\%).

4. Gambaran sel epitel berupa karsinoma mammae sebanyak 6 orang (20\%).

5. Gambaran epitel berupa mammary dysplasia, multiple fibroadenoma mammae dan ductal hyperplasia mammae masing - masing sebanyak 1 orang $(3,33 \%)$.

\section{DAFTAR PUSTAKA}

Atkins,K.A, Kong C.S., 2013. Practical Breast Pathology; A Diagnostic Approach. Philadhelpia; Elseviers Saunders.p.93 - 5.

Astutik RY. 2014. Payudara dan Laktasi. Jakarta: Salemba Medika Dashner R. 2011. Clinical Anatomy of the Breast. Ohio University.

Ellis IO. 2013. Invasive breast carcinoma. In: Tavasolli FA, Devilee $P$. Pathology and Genetic of Tumours of the Breast and Female Genital Organs WHO Classification of Tumours. IARC Press. 18 (19): 23 $-43$.

Hartati I. 2016. Peran Pemeriksaan FNAB dalam Penegakan Diagnosa Tumor. Buku Saku RSUD Kabupaten Sidoarjo.

Haryono SJ, Sukasah C, Swantari N. 2011. Payudara. Buku ajar ilmu bedah Edisi ketiga. Jakarta: EGC Penerbit Buku Kedokteran.

Hilbertina N. 2015. Peranan Patologi dalam Diagnostik Tumor Payudara. Majalah Kedokteran Andalas. 38 (1): 1 - 8.

Irwig LM, Bossuyt PM, Reitsma JB, Bruns DE, Gatsonis CA, Glasziou PP. 2012. Towards complete and accurate reporting of studies of diagnostic accuracy: the STARD initiative. Biological Molecular Journal. 3 (2): $4-41$.

Humaera R \& Mustofa S. 2017. Diagnosis dan Penatalaksanaan Karsinoma Mammae Stadium 2. Jurnal Medula Unila. 7 (2): 103 - 107.

Kementrian Kesehatan RI. 2014. Panduan Penatalaksanaan Kanker Payudara. Jakarta.

Kumar,V, Ramzi,SC \& Stanley LR. 2017. Robbins Buku Ajar Patologi,edk 7,Vol. 2, trans. BU Pendit. Jakarta; EGC. HIm: 791-793.

Mansel RE, Webster DJT, Sweetland HM. 2010. Benign Disorders and 
Bisease of the Breast. Saunders Elsevier.

Montag A \& Kumar V. 2017. The Female Genital System and Breast. Journal of Pathology. 1(8): 43 - 49.

Sjamsuhidajat \& De Jong W. 2005. Buku Ajar Ilmu Bedah, Edisi II. Jakarta: Penerbit Buku Kedokteran EGC.

Suen C, Kenneth. 2010. Fine Needle Aspiration Biopsy of Thyroid. CMAJ. 36: 167

Suyatno. 2015. Peran Pembedahan pada Tumor Jinak Payudara. Majalah Kedokteran Andalas. 38 (1): 12 27.

Syahruddin I. 2018. Nilai Diagnostik USG Gray Scale, Color Doppler dan Strain Elastography dalam Menentukan Keganasan Tumor Payudara. Program Studi IImu Radiologi Fakultas Kedokteran Universitas Hasanuddin.

Thor AD \& Osunkoya AO. 2010. The Breast. In: Rubin E, Strayer DS. Farber. Editors. Rubin's Pathology: Clinicopathologyc Fondation of Medicine. JB Lippincott Williams \& Wilkins; Philadelphia. 2(5): 42-53. 